\title{
An Assessment of Nutritional Status of under-five Children in Rural Area, Udaipur, Rajasthan, India
}

\author{
Sujata Sethy $^{1 *}$ and Renu Mogra ${ }^{2}$
}

${ }^{1}$ Krishi Vigyan Kendra, ICAR-National Rice Research Institute, Cuttack, Odisha, India

${ }^{2}$ Department of Food Science and Nutrition, College of Community and Applied Sciences, MPUAT, Udaipur, Rajasthan, India

*Corresponding author

\begin{tabular}{l} 
Ke y w o r d s \\
$\begin{array}{l}\text { Nutritional status, } \\
\text { Children, Rural } \\
\text { area, Underweight, } \\
\text { Stunting }\end{array}$ \\
Article Info \\
$\begin{array}{l}\text { Accepted: } \\
\text { 30 May 2020 } \\
\text { Available Online: } \\
\text { 10 June } 2020\end{array}$ \\
\hline
\end{tabular}

\section{A B S T R A C T}

The trend of undernourished children below five-year in India is showing declining pattern, but the pace of reduction is not matching with the criteria set by United Nation Development Project under millennium developmental goals for India. So it important to assess the nutritional status for implementing interventions to curb under nutrition with focus on high burden districts in the state. The objectives of the present study are to investigate the demographic profile and nutritional status among under-five children living in rural areas of Udaipur district of Rajasthan. This study was conducted among 224 rural children (boys and girls) aged 3-5 years. Anthropometric assessment for underweight, wasting and stunting was calculated based on age, weight and height measurements. As per WHO classification, underweight, stunting and wasting among the age group of 35 years children was $37.54,46.41$ and 16.73 percent respectively. It showed the highest prevalence for stunting, followed by underweight and least for wasting.

\section{Introduction}

Children in their early age need proper nutritional care not only to promote physical and mental growth but also to maintain their optimum health and nutritional status. In India, according to the National Family Health Survey (NFHS-4) in 2015-16, about 35.7 per cent children below five years were underweight, 38.4 per cent were stunted and
21 per cent were wasted. According to Census of India 2011, about $10.7 \%$ of population are in preschool age in India. As per the reports of world health organization (WHO) half of the malnourished children in the world live in Asia and Africa, including the children in India. In early childhood, malnutrition has grievous, long-term consequences as it impedes motor, cognitive, sensory, social as well as emotional development. It also costs 
lives as about 50 per cent of all childhood deaths are attributed to malnutrition. It was reported that in India the children below five years mortality rates contributing $22 \%$ of the World (WHO, 2013). Under-nutrition continues to be a major public health problem in most of the developing countries; nearly half of the children in India are unable to grow to their full physical and mental potential owing to under-nutrition. Malnutrition in children is not affected by food intake alone; it is also affected by access to health services, good hygiene practices and other condition. It is now well recognized by government and other organizations that improving the nutritional status of children in their early age can contribute to educational achievement of an individual and a country's socio-economic development in the long term. The government is planning to implement interventions to curb under nutrition with focus on high burden districts in the state. Therefore, the present study was carried out to assess the demographic profile and nutritional status of children under-five years of age in rural Udaipur.

\section{Materials and Methods}

Udaipur is one of the 33 districts of Rajasthan. The geographical boundaries of the district extend from 23.45 " to 24.8 " North Latitudes and from 73.9" to 74.35" East Longitudes and it's in the 583 meters to 259 meters elevation range from the sea level. Udaipur district has an estimated population of 26.33 million, $55 \%$ of which are tribal. The present study was carried out on children under-five years of age in rural areas of Udaipur district. A sample size of 224 children (3-5 years) were selected for the study, where 114 children were from 3-4 years and 110 children were from 4-5 years were randomly selected. Consent of parents or guardians of selected children were obtained prior to inclusion of children in the study. Nutritional status of pre-school children was assessed based on Anthropometric measurements viz. height $(\mathrm{cm})$ and weight $(\mathrm{kg})$ as per the guidelines suggested by Jelliffe (1966). Height was recorded to the nearest $0.1 \mathrm{~cm}$ and weight was recorded with minimum wearing clothing's measured to the nearest $0.1 \mathrm{~kg}$ using standard techniques.

\section{Classification of selected children based on anthropometry}

By using the recorded measurements different indices i.e. height for age, weight for age, weight for height and $\mathrm{z}$-score value or standard deviation units were calculated and classified into different degrees of malnutrition. WHO standards are used widely which is based on Z-scores or standard deviation units. Z-score or standard deviation unit is defined as the difference between the value for an individual and the median value of the reference population for the same age or height, divided by the standard deviation of the reference population. Children were classified based on Z-score as given below

Children who were more than two standard deviations below the reference median $(<-2$ $\mathrm{SD})$ on the basis of weight for age (WAZ), height for age (HAZ) and weight for height (WHZ) nutritional indices were considered to be underweight, stunted and wasted respectively (WHO,2006).

Statistical Analysis: Demographic information was collected from the parents by using questioner and the data was processed, scored, tabulated and descriptive statistics as well as simple proportion were calculated for the data. The SPSS (Statistical Package for the Social Sciences) version 23 and WHO Anthro software version 3.2.2 (World Health Organization, 2011) were used for analyzing data. WHO Z scores for anthropometric measurements were computed for boys and girls separately. 


\section{Results and Discussion}

A total of 224rural children of under-five age group were selected for the study and the results regarding their demographic profile were presented in Table 1. Among the selected children114 (50.9\%) were of 3-4 years and $110(49.1 \%)$ were of 4-5 years of age. It included 123 (54.9\%) male children and $101(45.1 \%)$ female children with sex ratio of 1.22:1.Similar pattern on selection of under-six children showed 52\% male and 48\% females by Deshmukh et al., (2007) in their study. About 36.2 percent children belong to general caste followed by 33.0 percent scheduled tribe. As Udaipur is a tribal dominated district $(55 \%)$ about one third of the selected rural children were belong to schedule tribe category. With respect to family type, about 56.7 per cent children were belonged to joint family and 43.3 percent children were belonged to nuclear family. Generally joint families are headed by oldest person of the family having traditional mindset restricting them to learn and adopt new knowledge, techniques and living practices Srivastava (2012) have also reported similar findings of family type in his study for school going children. About 41.5 percent children were from medium family set up followed by 31.7 percent from small and 26.8 percent were from large family size. Information collected on maternal education revealed that out of 224 children, mothers of 30.0 percent children were educated above secondary education, 24.1percentwere up to secondary education, 30.8 percent were having primary education and about 15.2 percent were illiterate. Similar pattern of maternal educational status was observed by Ghane and Kumar (2017) among under-five children. With respect to occupational status of the parents, it was observed that majority of fathers $(56.7 \%)$ were labourers followed by business/agriculture (36.1\%) and only 7.1 percent were salaried employee. Similarly among mothers of children majority were housewives $(65.2 \%)$ followed by labourer $(31.1 \%)$ and only 3.6 percent were salaried employee/self-employed. Majority of the family $(58.9 \%)$ had a monthly income in between five thousand to ten thousand rupees. From the selected children about 38.4 percent were first born and 37.9 were second born and rest 23.7 percent were third born and above. Majority $(62.05 \%)$ of family were having a vegetarian food habit.

Anthropometric measurements i.e. weight and height of children under-five enrolled in the investigation, were presented in the Table 2. It was observed that the mean weight of children in the age group of 3-4 years was $12.18 \mathrm{~kg}$ for male and $11.57 \mathrm{~kg}$ for female children where as in the age group of 4-5 years, it was $13.32 \mathrm{~kg}$ for male and $13.27 \mathrm{~kg}$ for female children. Weight of both the age group children was below the standard set by World Health Organization and differs significantly.

Height of children in the age group of 3-4 years was $91.12 \mathrm{~cm}$ and $88.87 \mathrm{~cm}$ for male and female children respectively where as in 4-5 years of age group it was $97.89 \mathrm{~cm}$ and $95.97 \mathrm{~cm}$ for male and female children respectively. The values were below the standard weight and the difference is statistically significant. Manjunath et al., (2014) and Kaur and Sen (2017) in their study on below 5 years children found that the mean observed height and weight of both boys and girls were below the reference height and weight.

This is a matter of concern as under nutrition causes a significant contribution in under-5 year children mortality. 
Table.1 Demographic profile of children (3-5 years)

\begin{tabular}{|c|c|c|c|c|}
\hline $\begin{array}{l}\text { Sl. } \\
\text { No. }\end{array}$ & Characteristics & Categories & $\begin{array}{l}\text { Frequency } \\
\text { (f) }\end{array}$ & $\begin{array}{c}\text { Percentage } \\
(\%)\end{array}$ \\
\hline \multirow[t]{2}{*}{1.} & \multirow{2}{*}{ Gender } & Male (M) & 123 & 54.9 \\
\hline & & Female (F) & 101 & 45.1 \\
\hline \multirow[t]{2}{*}{2.} & \multirow[t]{2}{*}{ Age (year) } & $3-4$ & $114(\mathrm{M}=61, \mathrm{~F}=53)$ & 50.9 \\
\hline & & $4-5$ & $110(\mathrm{M}=62, \mathrm{~F}=48)$ & 49.1 \\
\hline \multirow[t]{4}{*}{3.} & \multirow{4}{*}{ Caste } & General & 81 & 36.2 \\
\hline & & Scheduled Caste & 31 & 13.8 \\
\hline & & Scheduled Tribe & 74 & 33.0 \\
\hline & & Other Backward Caste & 38 & 17.0 \\
\hline \multirow[t]{2}{*}{4.} & \multirow[t]{2}{*}{ Family type } & Nuclear & 97 & 43.3 \\
\hline & & Joint & 127 & 56.7 \\
\hline \multirow[t]{3}{*}{5.} & \multirow[t]{3}{*}{ Family size } & Small (Upto 4 members) & 71 & 31.7 \\
\hline & & Medium (5-8 members ) & 93 & 41.5 \\
\hline & & $\begin{array}{l}\text { Large (9 members and } \\
\text { above) }\end{array}$ & 60 & 26.8 \\
\hline \multirow[t]{5}{*}{6.} & \multirow[t]{5}{*}{ Education of mother } & Illiterate & 34 & 15.2 \\
\hline & & Primary & 69 & 30.8 \\
\hline & & Secondary & 54 & 24.1 \\
\hline & & Higher secondary & 55 & 24.6 \\
\hline & & Graduate and above & 12 & 5.4 \\
\hline \multirow[t]{3}{*}{7.} & \multirow[t]{3}{*}{ Occupation of father } & Salaried employee & 16 & 7.1 \\
\hline & & Labourer & 127 & 56.7 \\
\hline & & Business/Agriculture & 81 & 36.1 \\
\hline \multirow[t]{3}{*}{8.} & \multirow[t]{3}{*}{ Occupation of mother } & Housewife & 146 & 65.2 \\
\hline & & Labourer & 70 & 31.3 \\
\hline & & Service/self-employed & 8 & 3.6 \\
\hline \multirow[t]{4}{*}{9.} & \multirow{4}{*}{$\begin{array}{l}\text { Monthly family } \\
\text { income (Rs.) }\end{array}$} & Upto 5000 & 18 & 8.0 \\
\hline & & 5000 to 10000 & 132 & 58.9 \\
\hline & & 10000 to 15000 & 63 & 28.1 \\
\hline & & Above 15000 & 11 & 4.9 \\
\hline \multirow[t]{3}{*}{10.} & \multirow{3}{*}{$\begin{array}{l}\text { Birth order of the } \\
\text { child }\end{array}$} & $1^{\text {st }}$ born child & 86 & 38.4 \\
\hline & & $2^{\text {nd }}$ born child & 85 & 37.9 \\
\hline & & $3^{\text {rd born and above }}$ & 53 & 23.7 \\
\hline \multirow[t]{3}{*}{11.} & \multirow[t]{3}{*}{ Family Food habit } & vegetarian & 139 & 62.05 \\
\hline & & Non-vegetarian & 26 & 11.60 \\
\hline & & Ovo-vegetarian & 58 & 25.89 \\
\hline
\end{tabular}


Table.2 Mean and SD of weight and height of study subjects

\begin{tabular}{|l|c|c|c|c|c|c|c|c|}
\hline Age (years) & $\begin{array}{c}\text { n } \\
(\mathbf{2 2 4})\end{array}$ & $\begin{array}{c}\text { Observed } \\
\text { height (cm) }\end{array}$ & Standard $^{\#}$ & $\begin{array}{c}\text { t- } \\
\text { value }\end{array}$ & $\begin{array}{c}\text { Observed } \\
\text { weight (kg) }\end{array}$ & Standard $^{\#}$ & $\begin{array}{c}\text { t- } \\
\text { value }\end{array}$ \\
\hline \\
\hline 3-4 yr. (n1) & 61 & $91.12 \pm 4.92$ & 99.84 & $17.34^{*}$ & $12.18 \pm 2.29$ & 15.34 & $19.03^{*}$ \\
\hline 4-5 yr. (n2) & 62 & $97.89 \pm 3.71$ & 106.94 & $19.20^{*}$ & $13.32 \pm 1.55$ & 17.42 & $20.73^{*}$ \\
\hline \multicolumn{7}{|c|}{ Female } \\
\hline 3-4 yr. (n3) & 53 & $88.87 \pm 3.91$ & 98.88 & $18.63^{*}$ & $11.57 \pm 2.05$ & 14.93 & $23.21^{*}$ \\
\hline 4-5 yr. (n4) & 48 & $95.97 \pm 4.83$ & 105.63 & $13.86^{*}$ & $13.27 \pm 1.39$ & 17.03 & $18.71^{*}$ \\
\hline
\end{tabular}

Table.3 Nutritional status of study subjects based on z-score (WHO classification)

\begin{tabular}{|c|c|c|c|c|c|c|}
\hline & \multicolumn{3}{|c|}{ Male $(n=123)$} & \multicolumn{3}{|c|}{ Female $(n=101)$} \\
\hline & $\begin{array}{c}\text { Height } \\
\text { for age } \\
(\%)\end{array}$ & $\begin{array}{c}\text { Weight } \\
\text { for age } \\
(\%)\end{array}$ & $\begin{array}{c}\text { Weight } \\
\text { for height } \\
(\%)\end{array}$ & $\begin{array}{c}\text { Height } \\
\text { for age } \\
(\%)\end{array}$ & $\begin{array}{c}\text { Weight for } \\
\text { age }(\%)\end{array}$ & $\begin{array}{l}\text { Weight } \\
\text { for height } \\
(\%)\end{array}$ \\
\hline Normal & $\begin{array}{c}14 \\
(11.38)\end{array}$ & $\begin{array}{c}24 \\
(19.51)\end{array}$ & $45(36.58)$ & $\begin{array}{c}09 \\
(08.91)\end{array}$ & $13(12.87)$ & $47(46.53)$ \\
\hline $\begin{array}{l}\text { Mild } \\
(<-1 \text { SD) }\end{array}$ & $\begin{array}{c}63 \\
(51.22)\end{array}$ & $\begin{array}{c}59 \\
(47.97)\end{array}$ & $55(44.72)$ & $\begin{array}{c}36 \\
(35.64)\end{array}$ & $45(44.55)$ & 39 (38.61) \\
\hline $\begin{array}{l}\text { Moderate } \\
\text { (<- 2 SD) }\end{array}$ & $\begin{array}{c}31 \\
(25.20)\end{array}$ & $29(23.58)$ & $23(18.70)$ & $\begin{array}{c}33 \\
(32.67)\end{array}$ & $31(30.69)$ & $13(12.87)$ \\
\hline $\begin{array}{l}\text { Severe } \\
(<-3 \text { SD })\end{array}$ & $\begin{array}{c}15 \\
(12.19)\end{array}$ & $11(8.94)$ & - & $\begin{array}{c}23 \\
(22.77)\end{array}$ & $12(11.88)$ & $2(1.98)$ \\
\hline
\end{tabular}

Fig.1 Malnutrition among study subjects

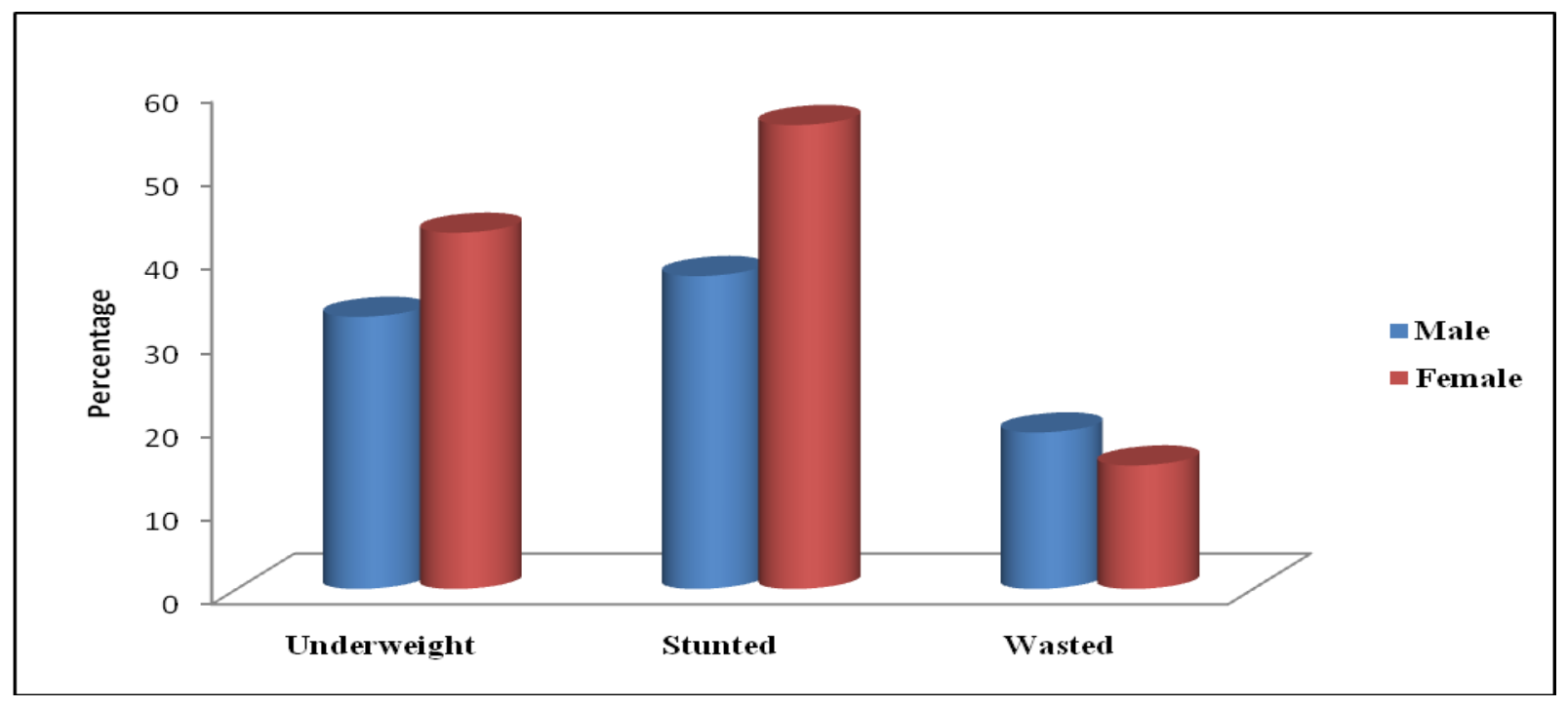


In the present study conducted in rural area, results were interpreted as module of WHO child growth standards on interpretation of nutritional status indicator and it was revealed (Table 3/Figure 1) that among male children, 25.20 percent were stunted and 12.19 percent were severely stunted, 23.58 percent were underweight and 8.94 were severely underweight, 18.70 percent were wasted and none of the children among male found severely wasted.

Accordingly among female children 32.67 percent children were stunted and 22.77 percent were severely stunted, 30.69 percent were underweight and 11.88 percent were severely underweight and 12.87 percent were wasted and 1.98 percent was severely wasted.

In the present study, perusal of result showed that under weight, stunting and wasting among the age group of 3-5 years children was 37.54, 46.41and 16.73 percent respectively. It showed the highest prevalence for stunting $(46.41 \%)$, followed by underweight $(37.54 \%)$ and least for wasting $(16.73 \%)$. Similar trends for prevalence were noticed in NFHS-4of Rajasthan (stunting $39.1 \%$, underweight $36.7 \%$, and wasting $23.0 \%$ ). It was also observed that proportion of wasting was higher among male children, whereas proportion of stunting and underweight was higher among female children. Similar finding was also reported by Gupta et al., (2019) in their study among children (1-5 years) of rural Haryana.

In conclusion, the result of this study revealed that existence of high prevalence of malnutrition, especially stunting among under-five children in this study area. Male children were taller and heavier than their female counterparts. It was also observed that among under-five children, the mean observed height and weight of both boys and girls were below the reference height and weight given by World Health Organization (WHO). Intervention efforts should focus broader than providing supplementary nutrition alone to address vulnerability of under-five age-groups to end under nutrition by 2030 as per Sustainable Development Goals.

\section{References}

Census of India, (2011).[Cited 2017 dec. 9]. Available from http://www.census.gov.in

Deshmukh, P.R., Dongre, A.R., Gupta, S.S. and Garg, B.S. (2007). Newly developed WHO growth standards: Implications for demographic surveys and child health programs. Ind. J Ped. 74(11): 987-90

Ghane, V.R. and Kumar, R. (2017). Nutritional status of under-five children of Mumbai suburban region. Inter. Jour of Res in Med. Sci. 5(7):3190-3196.

Gupta, V., Chawla, S. and Mohapatra, D. (2019). Nutritional assessment among children (1-5 years of age) using various anthropometric indices in a rural area of Haryana, India. Ind. $J$ Com. Fam. Med. 5:39-43.

Jelliffe, D.B. (1966). The assessment of the nutritional status of the community. World Health Organization Monograph, Geneva; 53(3):50-84.

Kaur, D and Sen, M. (2017). Study on the Incidence of Malnutrition in Children (1-5 Years) of Low Income Group. Inter. Jour of Eng. Tech. Sci. and Res. 4 (7):436-445

Manjunath, R., Kumar, J.K., Kulkarni, P., Begum K., Gangadhar, M.R. (2014). Malnutrition Among Under-Five Children of Kadukuruba Tribe: Need to Reach the Unreached. Jour. of Cli. and Diag. Res., 8(7): 01-04

Srivastava, A., Mahmood, S.E., Srivastava, P.M., Shrotriya, V.P. and Kumar, B. 
(2012) Nutritional status of school age children - a scenario of urban slums in India. Arch. Public Health. 70(3):1-8.

WHO, (2013).Global child deaths.[Cited 2019 on Jan 14]. Available from http://www.who.int/mediacentre/news/r eleases/2013/child_mortality_causes_20 130913/en/index.html World Health Organization (2011). WHO Anthro for personal computers, version 3.2.2, 2011: Software for assessing growth and development of the world's children. WHO, Geneva.

\section{How to cite this article:}

Sujata Sethy and Renu Mogra. 2020. An Assessment of Nutritional Status of under-five Children in Rural Area, Udaipur, Rajasthan, India. Int.J.Curr.Microbiol.App.Sci. 9(06): 39473953. doi: https://doi.org/10.20546/ijcmas.2020.906.463 